\title{
Przewodnik po świecie filozofii
}

J. Baggini, P. Fosl, Przybornik filozofa. Kompendium metod i pojęć filozoficznych, Instytut Wydawniczy PAX, Warszawa 2010, s. 328.

Książka, nosząca tytuł Przybornik filozofa. Kompendium metod $i$ pojęć filozoficznych została napisana przez dwóch myślicieli wywodzących się z anglosaskiego paradygmatu myślenia, czy tė̇ specyficznej angielsko-amerykańskiej drogi podejmowania procesu refleksji filozoficznej. Głównym autorem recenzowanej książki jest Julian Baggini - filozof pochodzący z Anglii, redagujący swój magazyn o tematyce filozoficznej. Julian Baggini wydał także inne książki mające na celu popularyzowanie i wyjaśnianie problemów z obszaru tematyki filozoficznej. Drugi autor, Peter S. Fosl jest profesorem na amerykańskim uniwersytecie w stanie Kentucky.

Celem, który przyświeca autorom recenzowanej książki, jest ukazanie specyfiki terminologii i wiedzy wyrażonej zestawem określonych narzędzi, działających na polu ujmowania rzeczywistości jaka jest filozofia. Filozofia, tak jak inne dziedziny nauki, operuje określonymi ścisłymi terminami, pojęciami i definicjami, które ujęte $\mathrm{w}$ horyzoncie dynamiki myśli, rodzą sposoby rozumowania zachowujące dyscyplinę wedle obranej metody. Dlatego téz książka ta jest trudną lekturą ilustrującą nam, że filozofia rodzi się z materiału nagromadzonej wiedzy i dyscypliny myślenia.

Autorzy dzielą książkę na sześć głównych rozdziałów. Rozdział pierwszy: „Podstawowe narzędzia argumentacji”, rozdział drugi: „Dalsze narzędzia argumentacji”, rozdział trzeci: „Narzędzia oceny”, rozdział czwarty: „Narzędzia rozróżnienia pojęciowego", rozdział piąty: "Narzędzia krytyki radykalnej”, rozdział szósty: „Narzędzia u kresu”. Wymienione rozdziały podzielone są 
na określone podrozdziały, czego efektem jest przejrzystość i zachowanie swoistego continuum szczegółowego rozwijania głównego problematu, zawartego w każdym tytule rozdziału.

Rozdział pierwszy stanowi wprowadzenie do sposobu rozumowania w filozofii. Rozumownie filozoficzne rozpoczyna się od podstawowego elementu, jakim jest argument. Tak oto Baggini i Fossl definiują argument: „W odróżnieniu od tego wszystkiego filozofowie używają terminu «argumentacja» w bardzo precyzyjnym i wąskim sensie. Argument to dla nich najbardziej podstawowa jednostka rozumowania, atom rozumu" ${ }^{1}$. Na podstawie tego cytatu stwierdzamy, że autorzy recenzowanej książki kładą nacisk na wyraźne oddzielenie języka naturalnego, potocznego od języka sztucznego, filozoficznego. Sam bowiem argument zyskuje wąskie znaczenie atomu rozumowania. Atom rozumowania porusza się będąc najpierw punktem wyjścia, czyli przesłanką, kończy swój bieg stając się wnioskiem. Po wprowadzeniu nas w świat przesłanki i wniosku, w rozdziale pierwszym możemy poznać różnice pomiędzy rozumowaniem dedukcyjnym oraz doświadczalną indukcją. Będąc świadomi typów rozumowania zostajemy pouczeni przez autorów o obalaniu oraz błędach, które zawsze zagrażają nam $\mathrm{w}$ procesie rozumowania. $\mathrm{W}$ rozdziale początkowym zostaje także omówione pojęcie aksjomatu oraz definicji. Uważam za bardzo trafne że Baggini i Fossl zwracają uwage na wielkie znaczenie jakie ma proces definiowania w filozofowaniu. Podkreślają oni, że należy w sposób jasny definiować pojęcia, aby można było poprawnie komunikować swoje rozumowanie innemu podmiotowi.

Rozdział drugi przybliża nam rozumowanie mające charakter abdukcji, polegającej na dobieraniu odpowiedniego wyjaśnienia. Autorzy posługują się barwną kryminalną historią, która w sposób obrazowy świetnie ilustruje ten typ rozumowania. Historia kryminalna ukazuje nam fakt popełnionej zbrodni, do której wyjaśnienia możemy użyć kilka różnych biegów wydarzeń. Okazuje się, że wszystkie biegi wydarzeń potencjalnie wyjaśniają daną

${ }^{1}$ J. Baggini, P. Fosl, Przybornik filozofa. Kompendium metod i pojęć filozoficznych, Instytut Wydawniczy PAX, Warszawa 2010, s. 11. 
zbrodnię, ale tylko jeden bieg wydarzeń doprowadził do określonej zbrodni. W tym momencie uruchamiamy abdukcję i szukamy tego najbardziej prawdopodobnego. W rozdziale tym wyjaśniona zostaje także dialektyka będąca twórczą walką dwóch przeciwieństw tworzących nowy trzeci element. Zostaje także podkreślona rola wyobraźni jako pomocnego elementu w filozofowaniu. Tworzenie określonych myślowych wyobrażeń może ułatwiać nam rozumienie wysoce abstrakcyjnych problemów. Wyobraźnia, zdaniem autorów, staje się odpowiednikiem laboratorium, w których filozof może przeprowadzać poważne eksperymenty myślowe, regulując pewne zmienne obecne $\mathrm{w}$ danym eksperymencie.

W trzecim rozdziale Baggini i Fossl badają elementy składające się na ocenę wyników naszego rozumowania. Ocena bowiem to kluczowy moment, w którym decydujemy się utrzymać, zmodyfikować lub odrzucić określone wyniki naszego filozofowania. W rozdziale tym autorzy inspirują się nauką Davida Hume: dzielą nasze sądy na konieczne, czyli te, które wynikają ze stosunku między koniecznym ideami oraz na sądy prawdopodobne, które powstały na podstawie określonych faktów ${ }^{2}$. W ostatnim podrozdziale odnajdujemy ciekawy wywód dotyczący sprawdzalności. Autorzy przybliżają nam sylwetkę Alfreda Ayera, będącego gorącym orędownikiem pojęcia sprawdzalności. Wydaje się, że właśnie sprawdzalność, będąca prostym zmysłowym potwierdzaniem doświadczalnym tego co sensowne, powinna dawać pewność oceny. Okazuje się jednak, że ogólność teorii naukowych ośmieszyła efektywność sprawdzalności, a z pomocą przyszły hipotezy Karla Poppera których skuteczność zawarta jest w falsyfikowaniu, będącym procesem naukowego poznania, otwartego na możliwość zmiany i nowości poznawczej. Moment ten, dotyczący filozofii nauki, jest najbardziej ekscytującą częścią kończącą rozdział trzeci.

Rozdział czwarty skoncentrowany jest wokół zagadnienia pojęcia i sposobów jego różnicowania. Ukazane są tutaj podstawowe pojęcia filozoficzne jak istota i przypadłości. Uważam, że najciekawszy fragment tego rozdziału dotyczy pojęcia semantyki

\footnotetext{
${ }^{2}$ Tamże, s. $139-140$.
} 
i syntaktyki. Autorzy poprzez analizę znaczenia i składni pokazują nam, że nowoczesne trendy filozofowania koncentrują się na języku. Filozofia języka okazuje się być bardzo owocna w aktualnym problemie sztucznej inteligencji. Autorzy, podobnie jak J. Searle, potwierdzają tezę, że koniecznym elementem do rozbłyśnięcia sztucznej inteligencji jest możliwość autonomicznego odbioru przez komputer czy robota, określonej treści znaczącej, będącej zagadnieniem semantyki. Do momentu kiedy maszyny będą funkcjonowały na zasadzie samych związkow fromalnych syntaktyki, będą one działające, ale nie w sposób inteligentny, którego wymogiem zaistnienia jest semantyczna autonomia ${ }^{3}$. Jest to bardzo ważny przykład tej książki ilustrujący nam, że dziedzina filozofii nie jest nauką z przeszłości, w każdym wieku rodzą się bowiem nowe problemy filozoficzne, które domagają się od nas nowych sposobów procedur myślenia filozoficznego.

Rozdział piąty wprowadza czytelnika w różne odcienie krytyki filozoficznej. Czytając kolejne stronice odkrywamy, że krytyka może dotyczyć bardzo różnych obszarów rzeczywistości. Można bowiem za przykładem filozofa Karola Marksa tworzyć krytykę opartą na fundamencie bytu społecznego i walki klasowej. Zupełnie inny rodzaj krytyki tworzy Jean Paul Seartre szukając poprzez nią horyzontu absolutnej wolności. Ukazana jest nawet krytyka feministyczna, która w dyskryminacji płci żeńskiej oraz maskulinizacji pojęć abstrakcyjnych widzi cały obecny porządek rzeczywistości. Wydaje się, że autorom w tym rozdziale chodzi o nakreślenie uniwersalnego charakteru krytyki filozoficznej, obejmującej całość rzeczywistości. Drugim celem wydaje się być wykazanie, że krytyka nie jest wcale działaniem destrukcyjnym, lecz jest ona w swej istocie działaniem twórczym, ukazującym nam pewne nieuświadomione mechanizmy. Dlatego po przeczytaniu tego rozdziału możemy zrozumieć, że wyostrzona świadomość to pozytywny efekt twórczego działania krytyki.

Ostatni rozdział, kończący całość książki, zaprezentowany jest jako swoisty kres. Filozofia jest ciągłym doświadczaniem kresu

${ }^{3}$ Tamże, s. 239. 
rozumienia, ale rozumienia, które idzie dalej i szuka w sposób kreatywny nowych rozwiązań. Autorzy uczą nas, że sceptycyzm jest bardzo kreatywny, ponieważ dynamizuje nasz badawczy pochód, z drugiej strony może jednak siać samą destrukcję bez ciekawych rozwiązań. Wydaje się, że sam koniec książki jest próbą ukazania perspektywy filozofowania. Zostajemy pouczeni przez autorów, że należy szukać pewnego fundamentu myślenia zawartego w pojęciach oczywistych. Filozof na tle poglądów zawartych w recenzowanej przez nas książce to badacz, który nieustannie kreuje nowe drogi rozwiązywania nawet najtrudniejszych problemów.

Po zaprezentowaniu treści nadszedł czas na ocenę książki. Uważam, że książka jest napisana w sposób uporządkowany, dlatego też bez problemu możemy odnaleźć hasła, które nas interesują. Sama treść adresowana jest do szerokiej rzeszy odbiorców. Książka ta bowiem może być pomocna w stawianiu pierwszych kroków w świecie filozofii, ale także zawansowani myśliciele odnajdą w niej możliwość szybkiej rewizji swojej wiedzy. W każdym rozdziale odnajdujemy krótkie historie życiowe, będące obrazowaniem problemów filozoficznych co ułatwia zrozumienie i wyrywa z monotonii suchego specjalistycznego języka. Po uważnej lekturze książki możemy odkryć, że autorzy prezentują nam unikalne rozumienie dziedziny filozoficznej. Filozofia w ich rozumieniu jest bowiem progresywnym przejściem od dyskursu filozoficznego, istotnie wyrażonego jako całościowa refleksja, do filozofii jako dziedziny badawczej. Ścisłość terminów, określoność systemów oraz atomowy charakter argumentów odsłania przed nami droge filozofi, będącej ścisłym badaniem problemów czekających na rozwiązanie. Uważam jednak że w książce zabrakło dokładniejszego omówienia zagadnienia idei u Platona. Jest to podstawowe zagadnienie filozoficzne, które powinno być znane każdemu początkującemu filozofowi. Brakuje także ujęcia podstawowych problemów z dziedziny etyki. Ciągły spór na temat autonomii istnienia wartości, rozróżnienia na dobra i wartości, kwestia istnienia moralności naturalnej to bardzo żywe etyczne problemy które zostały pominięte w książce. Trzeba jednak przyznać że bogactwo treści książki 
w sposób bardzo efektywny dociera do dużej ilości podstawowych problemów zawartych w filozoficznym uniwersum. Książka ta jest godna polecenia, ponieważ ma charakter swoistego przewodnika po świecie filozofii. Dlatego też wyruszając w kolejną intelektualną podróż, pełną nowych zagadnień, dzięki przewodnikowi usprawnimy swoje rozumienie doświadczając coraz częściej poczucia trywialności.

Maksymilian Czaja 